\title{
Estimation and Mapping of Wet and Dry Mercury Deposition Across Northeastern North America
}

\author{
ERIC K. MILLER, ${ }^{1, *}$ ALAN VANARSDALE, ${ }^{2}$ GERALD J. KEELER, ${ }^{3}$ ANN CHALMERS, ${ }^{4}$ \\ LAURIER POISSANT, ${ }^{5}$ NEIL C. KAMMAN ${ }^{6}$ AND RAYNALD BRULOTTE ${ }^{7}$ \\ ${ }^{1}$ Ecosystems Research Group, Ltd., PO Box 1227, Norwich, VT 05055, USA \\ ${ }^{2}$ United States Environmental Protection Agency, N. Chelmsford, Massachusetts \\ ${ }^{3}$ University of Michigan Air Quality Laboratory, Ann Arbor, Michigan \\ ${ }^{4}$ United States Geological Survey, Montpelier, VT USA \\ ${ }^{5}$ Atmospheric Toxic Processes, Meteorological Service of Canada, Environnement Canada, Montréal, \\ Québec Canada \\ ${ }^{6}$ Water Quality Division, Department of Environmental Conservation, Vermont Agency of Natural \\ Resources, Waterbury, VT USA \\ ${ }^{7}$ Ministère de l'environnement du Québec, Ste-Foy, Québec Canada
}

Accepted 4 December 2004

\begin{abstract}
Whereas many ecosystem characteristics and processes influence mercury accumulation in higher trophic-level organisms, the mercury flux from the atmosphere to a lake and its watershed is a likely factor in potential risk to biota. Atmospheric deposition clearly affects mercury accumulation in soils and lake sediments. Thus, knowledge of spatial patterns in atmospheric deposition may provide information for assessing the relative risk for ecosystems to exhibit excessive biotic mercury contamination. Atmospheric mercury concentrations in aerosol, vapor, and liquid phases from four observation networks were used to estimate regional surface concentration fields. Statistical models were developed to relate sparsely measured mercury vapor and aerosol concentrations to the more commonly measured mercury concentration in precipitation. High spatial resolution deposition velocities for different phases (precipitation, cloud droplets, aerosols, and reactive gaseous mercury (RGM)) were computed using inferential models. An empirical model was developed to estimate gaseous elemental mercury (GEM) deposition. Spatial patterns of estimated total mercury deposition were complex. Generally, deposition was higher in the southwest and lower in the northeast. Elevation, land cover, and proximity to urban areas modified the general pattern. The estimated net GEM and RGM fluxes were each greater than or equal to wet deposition in many areas. Mercury assimilation by plant foliage may provide a substantial input of methyl-mercury ( $\mathrm{MeHg}$ ) to ecosystems.
\end{abstract}

Keywords: mercury; Hg; GEM; RGM; atmospheric deposition; North America

\section{Introduction}

*To whom correspondence should be addressed: Tel.: 802-356-5043; Fax: 802-649-5551;

E-mail: ekmiller@ecosystems-research.com
Most of the mercury burden in rural and remote landscapes is due to atmospheric transport and deposition of anthropogenic emissions. Biogeochemical 
processes transform a portion of this deposited mercury to bioavailable $\left(\mathrm{Hg}^{2+}\right.$ and $\left.\mathrm{MeHg}\right)$ forms which accumulate in the tissues of plants and animals. Elevated blood and tissue mercury concentrations lead to a variety of health effects on both wildlife and human consumers of mercury containing foods (National Academy of Sciences, 2000).

While large numbers of geographically distributed observations of mercury levels in sediments and biota are available (see papers in this volume), atmospheric deposition of mercury has only been quantified at a small number of locations. Where mercury deposition has been measured, generally only the wet deposition (rain + snow) flux has been monitored. Various modeling and observational studies have demonstrated that dry deposition processes may contribute amounts of mercury to the landscape equal to or greater than wet deposition (Grigal, 2002; Cohen et al., 2004). Fine spatial-scale patterns such as local variation in vegetation type (receptor surface) and microclimate may be important determinants of the watershed-scale capture of atmospheric mercury.

Some deposited mercury is reemitted to the atmosphere as gaseous elemental mercury (GEM) relieving some of the atmospherically deposited mercury burden at a given site. A portion of the landscape mercury emission occurs directly from water or soil surfaces (Poissant and Casmir, 1998) whereas another portion results from emission from plant canopies (Lindberg et al., 1998; Poissant et al., 2004). The latter mechanism has received limited study and is poorly understood, but is thought to represent a potentially large return of mercury to the atmosphere (Lindberg et al., 1998; Lindberg and Meyers, 2001). There are various mechanisms in the marine and non-marine environment that lead to the oxidation of reemitted GEM and its eventual dry deposition (Poissant et al., 2004) or scavenging by cloud or rain drops (Lin and Peknonen, 1999). Thus, the mercury stored in soils and sediments of rural locations from previous decades of elevated mercury deposition (Kamman and Engstrom, 2002) presently serves as an important wide-area source of GEM.

The purpose of this study is to generate initial estimates of total atmospheric mercury deposition from wet and dry deposition modes across Northeastern North America. The estimates are derived from observations of atmospheric mercury concentrations in predominantly rural environments made by several monitoring networks and do not take into account specific point sources. The estimates are intended to provide a picture of broad regional patterns in atmospheric deposition to rural landscapes and high spatial-resolution deposition estimates for comparison with observations of mercury levels in soils, sediments and biota. Estimates of ecosystem emission of GEM and atmospheric deposition near specific point sources are the subject of current research.

\section{Methods}

\section{Concentrations of mercury species in the atmosphere}

There are few direct measurements of mercury in precipitation and the atmosphere relative to the information currently available for estimation of other important air pollutants $\left(\mathrm{S}, \mathrm{N}, \mathrm{O}_{3}\right)$ in northeastern North America. However, the information that is available is perhaps one of the best regional data sets currently available for atmospheric mercury. The data used to estimate the regional concentration fields for atmospheric mercury species were obtained from the National Atmospheric Deposition Program, Mercury Deposition Network (MDN) and regional studies conducted by Environment Canada (EC), United States Environmental Protection Agency (USEPA), Northeast States for Coordinated Air Use Management (NESCAUM), and the United States Geological Survey (USGS).

\section{Mercury in precipitation}

We used data from 27 locations within the study area where mercury has been measured in precipitation (Table 1) as part of three mercury monitoring networks. All network sites measure total mercury in precipitation but use different samplers, protocols and analytical laboratories. The MDN protocol specifies weekly sample collections, while the EPA/NESCAUM-REMAP stations followed the University of Michigan Air Quality Laboratory (UMAQL) protocol that specifies event collections (Burke et al., 1995). The USGS stations follow a protocol similar to MDN but use different collectors and analytical facilities, and 
Table 1. Atmospheric mercury monitoring stations used in this study

\begin{tabular}{|c|c|c|c|c|c|c|c|c|c|c|}
\hline Station & $\mathrm{ST} / \mathrm{PR}$ & Network & $\operatorname{Mode}(s)^{a}$ & $\operatorname{Elev}(\mathrm{m})$ & Latitude & Longitude & Fall & Spring & Summer & Winter \\
\hline Beverly & MA & USGS & ppt & 34 & 42.58333 & -70.91667 & na & 7.2 & na & na \\
\hline Quabbin & MA & UMAQL & ppt, TGM, p & 312 & 42.29830 & -72.33470 & 7.1 & 9 & 12.48 & 6.37 \\
\hline Blue Hill & MA & USGS & ppt & 197 & 42.21667 & -71.11667 & 4.33 & na & na & na \\
\hline Greenville & $\mathrm{ME}$ & MDN & ppt & 322 & 45.48970 & -69.66440 & 4.54 & 4.79 & 9.09 & 3.19 \\
\hline Acadia & $\mathrm{ME}$ & MDN & ppt & 129 & 44.37390 & -68.26060 & 5.16 & 6.49 & 12.15 & 3.91 \\
\hline Bridgton & $\mathrm{ME}$ & MDN & ppt & 222 & 44.10750 & -70.72890 & 4.68 & 6.3 & 11.16 & 4.22 \\
\hline Casco Bay & $\mathrm{ME}$ & MDN & ppt & 15 & 43.83190 & -70.06280 & 5.97 & 6.41 & 11.58 & 4.92 \\
\hline St. Andrews & NB & MDN & ppt, TGM & 10 & 45.08330 & -67.08330 & 5.37 & 7.11 & 10.93 & 3.86 \\
\hline Cormak & NF & MDN & ppt & 168 & 49.31670 & -57.38330 & 3.32 & 5.17 & 7.21 & 2.47 \\
\hline Laconia & $\mathrm{NH}$ & MDN & ppt & 216 & 43.56167 & -71.49667 & 5.9 & 6.63 & 8.81 & 3.81 \\
\hline New Castle & NH & MDN & ppt & 10 & 43.16670 & -70.86670 & 6.21 & 6.2 & 11.36 & 4.29 \\
\hline Manchester & $\mathrm{NH}$ & USGS & ppt & 72 & 42.99500 & -71.46333 & na & na & na & na \\
\hline Kejimkujik & NS & MDN & ppt, TGM & 155 & 44.43280 & -65.20560 & 4.23 & 5.95 & 10.03 & 3.73 \\
\hline Huntington & NY & MDN & ppt & 500 & 43.97310 & -74.22310 & 5.52 & 6.86 & 9.2 & 4.95 \\
\hline Dorset & $\mathrm{ON}$ & MDN & $\mathrm{ppt}$ & 320 & 45.22390 & -78.93110 & 11.91 & 9.51 & 12.47 & 5.24 \\
\hline Egbert & $\mathrm{ON}$ & MDN & ppt, TGM & 251 & 44.23330 & -79.78330 & 7.24 & 12.25 & 10.38 & 4.92 \\
\hline Point Petre & $\mathrm{ON}$ & MDN & ppt & 78 & 43.84280 & -77.15360 & 6.01 & 6.97 & 12.57 & 7.18 \\
\hline Erie & PA & MDN & ppt & 177 & 42.15580 & -80.11340 & 8.65 & 9.77 & 12.41 & 8.69 \\
\hline Hills Creek & PA & MDN & ppt & 476 & 41.80430 & -77.19030 & 6.45 & 7.62 & 11.37 & 5.15 \\
\hline Milford & PA & MDN & ppt & 212 & 41.32750 & -74.82030 & 5.08 & 12.52 & 12.76 & 6.82 \\
\hline Allegheny Portage & PA & MDN & ppt & 739 & 40.45700 & -78.56000 & 8.41 & 9.15 & 12.99 & 6.7 \\
\hline Valley Forge & PA & MDN & ppt & 46 & 40.11660 & -75.88330 & 7.99 & 12.12 & 11.15 & 7.89 \\
\hline Arendtsville & PA & MDN & ppt & 269 & 39.92310 & -77.30780 & 5.4 & 11.02 & 12.15 & 9.05 \\
\hline Holbrook & PA & MDN & ppt & 1140 & 39.81610 & -80.28500 & 7.94 & 10.4 & 12.25 & 6.71 \\
\hline Mingan & PQ & MDN & ppt, TGM & 11 & 50.26670 & -64.23330 & 4.68 & 5.05 & 7.07 & 3.33 \\
\hline St. Anicet & PQ & MDN & ppt. TGM & 49 & 45.20000 & -74.03330 & 8.05 & 8.42 & 10.42 & 5.79 \\
\hline East Providence & RI & UMAQL & ppt, TGM, p & 20 & 41.84030 & -71.36170 & 7.66 & 9.89 & 10.15 & 5.81 \\
\hline Underhill & VT & UMAQL & ppt, TGM, p & 420 & 44.52830 & -72.89620 & 7.05 & 8.07 & 8.94 & 5.82 \\
\hline
\end{tabular}

Modes $=$ measurement modes: ppt $=$ precipitation mercury, TGM = total gaseous mercury, $\mathrm{p}=$ suspended particulate mercury. Seasonal precipitation-weighted mean mercury concentrations (ng $\mathrm{l}^{-1}$ ) are given for the maximum period of record for each station prior to 2002. Note: na $=$ not available; either data were only available for 2002 or later, or completeness criteria were not met for observations prior to 2002 .

allow a variable period of 1-3 weeks between collections. Protocol inter-comparison studies have been conducted that allow scaling of observations made by one network to match another network. For example, Alter (2000) identified a 9-22\% weekly bias (REMAP higher) in mercury concentration between co-located samplers using the different samplers, protocols and analytical laboratories for weeks with single and multiple events, respectively. Subsequent co-location trials involving the two differing samplers and protocols but the same (MDN) analytical laboratory found a smaller bias (Clyde Sweet, personal communication, 2002). Our analysis of the co-located data from the MDN and REMAP site at Acadia National Park indicates that on a monthly volume-weighted average basis, the REMAP protocol determined an average of $16 \%$ higher mercury concentrations than the MDN protocol. The relation between the monthly averages of the two protocols was best modeled by

$$
\mathrm{Hg}_{\mathrm{MDN}}=0.86 * \mathrm{Hg}_{\mathrm{REMAP}}
$$

$\left(r^{2}=0.95, p<0.0001, n=8\right)$ where MDN and REMAP represent the respective monthly volume-weighted average concentrations of mercury in precipitation (ng $1^{-1}$ ) determined by those protocols. An intercomparison of USGS and MDN protocols at Laconia, $\mathrm{NH}$ determined the same relative bias with the USGS protocol yielding higher estimates. Concentrations measured at USGS and REMAP sites were adjusted for bias using Equation 1 for comparison with the MDN network and generation of regional concentration fields. It is not known at this time which protocol provides the most accurate 
measurements. Therefore, the results presented below could be underestimates of the true concentration and deposition.

The mercury data from all stations were screened according to quality-assurance criteria. Monthly averages were computed only when $>90 \%$ of measured monthly precipitation was represented by valid samples. Seasonal averages were computed only for complete monthly records. Precipitation weighting was conducted based on measurements from dedicated precipitation gages rather than from collected sample volumes.

Because of differences in the objectives and funding of the different monitoring networks, there was no year when all stations operated simultaneously. Most stations operated from 1997 or 1998 to 1999. Alter (personal communication, 2001) examined the year-to-year variance in monthly concentrations at long-operating sites from both networks and determined that there was no evidence for large year-to-year differences in concentrations during the period including all observations. The coefficient of variation of annual volume-weighted mean concentrations was 9.2\% for Underhill (1993-1999) and 9.6\% for Acadia National Park (1997-2000), approaching the likely precision of the measurement. We did find a significant year effect in an analysis of covariance of seasonal volume-weighted mean concentrations (Fig. 1), but the only year significantly different from the mean was 2002. As a first approximation, and given year-to-year variance across the network of less than $10 \%$, it is reason- able to pool the observations from different years (excluding 2002) at different sites as a basis for forming the densest network possible for spatial interpolation of the mercury-precipitation concentration field. A primary objective of this study was to estimate the relative differences in mercury atmospheric deposition to lake watersheds across the region for comparison with differences in mercury burdens of various ecosystem compartments. Because most measures of ecosystem mercury accumulation integrate across years (or decades) of mercury deposition, pooling all years of available data is more appropriate for this study than conducting an analysis for individual years. This process of temporal aggregation to achieve greater spatial representation produces estimates that characterize regional patterns of mercury deposition rather than represent any specific year.

Monthly precipitation-weighted average concentrations (adjusted to an MDN basis) were averaged to seasonal precipitation-weighted concentrations (Table 1). The seasonal concentrations were spatially interpolated to a $1-\mathrm{km}$ grid over the region using inverse distance-squared weighting of observations (e.g. Fig. 2).

\section{Mercury in cloud-water, frost, or dew}

The few measurements of mercury in cloud-water, frost or dew (e.g. Lawson, 1999; Malcolm and Keeler 2002; Malcolm et al., 2003) indicate that mercury is not enriched with respect to its concentration in precipitation as is the case for more soluble compounds. This behavior is expected given the low RGM and particulate-mercury $\left(\mathrm{H}_{\mathrm{p}}\right)$
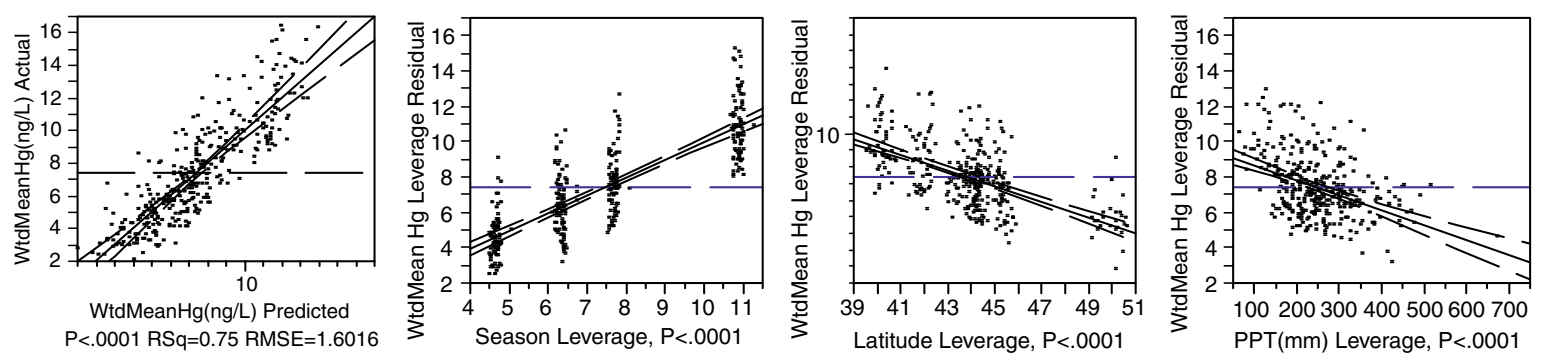

Figure 1. Analysis of covariance model for mercury concentrations in precipitation. Latitude and precipitation (PPT) were covariates. Season and year were main effects. Seasonal precipitaton-weighted mean mercury concentration decreased with increasing latitude and with increasing precipitation amount. There was a significant effect of season $(p<0.0001)$ with strong leverage. The seasonal means ranked as follows: winter (4.93 $\mathrm{ng} 1^{-1}$ ), fall (6.21), spring (7.52), and summer (11.02). There was a significant $(p=0.0005)$ year effect. Year leverage (not shown) was trivial with only the year $2002(6.74 \pm 0.18)$ significantly different from and slightly smaller than the mean response (7.45). 


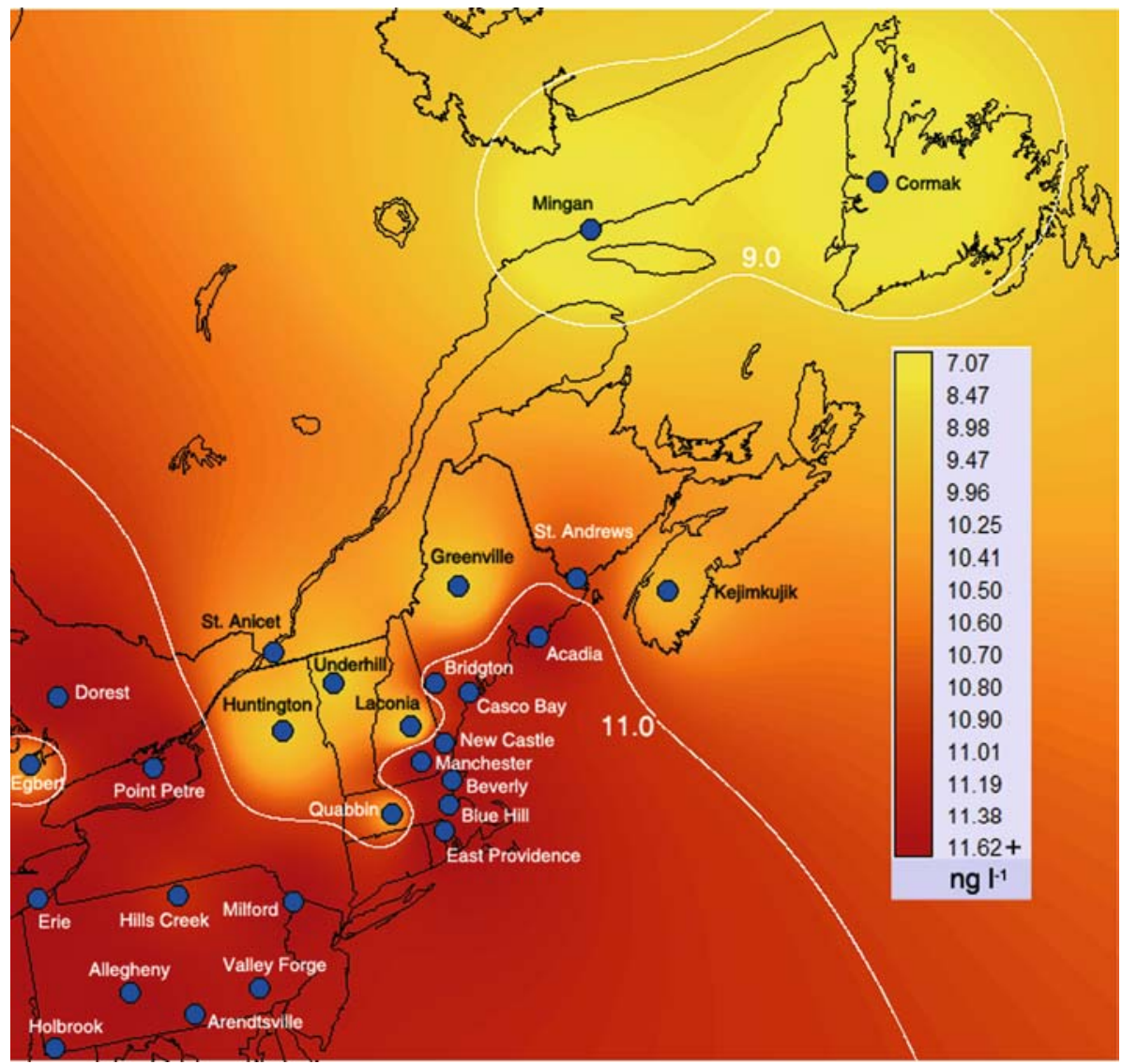

Figure 2. Estimated mercury concentration (ng $\mathrm{l}^{-1}$ ) field for summer precipitation. Blue circles represent the location of mercury monitoring stations (Table 1) used in the interpolation of the regional concentration field. Contours (white) are shown for the $9.0 \mathrm{ng} \mathrm{l}^{-1}$ and $11.0 \mathrm{ng}^{-1} \mathrm{Hg}$ concentration levels.

concentrations in the atmosphere and the very low solubility of $\mathrm{Hg}^{0}$ in water. We estimated the concentration of mercury in cloud-water from the precipitation concentration corrected for a slight enrichment (1.1) and spatial variations in cloud liquid water content (Miller et al., 1993a, b).

\section{Particulate-phase mercury}

Particulate $(<2.5 \mu \mathrm{m})$ mercury concentrations $\left(\mathrm{Hg}_{\mathrm{p}}\right)$ in air were determined at the three REMAP sites (Table 1) using UMAQL protocols (Burke et al., 1995). $\mathrm{Hg}_{\mathrm{p}}$ concentrations were lower in summer and higher in winter at all three sites, with seasonal differences more pronounced than site-tosite differences. The variation in $\mathrm{Hg}_{\mathrm{p}}$ concentrations could be modeled across the REMAP sites as a linear function of the mercury concentration in precipitation and season $\left(r^{2}=0.71, p=0.046\right.$, $n=12$ ). Particulate mercury concentrations throughout the region were estimated using this model. As discussed below, particulate-mercury deposition amounts to less than a few percent of total mercury deposition. Thus, the considerable uncertainty in particulate mercury concentrations resulting from the few measurements available has little effect on the uncertainty of the total mercury deposition estimate.

\section{$T G M, G E M$ and $R G M$}

Total gaseous mercury (TGM) is composed of gaseous elemental mercury (GEM) and reactive gaseous mercury $\left(\mathrm{RGM}=\mathrm{HgCl}_{2}+\mathrm{HgBr}_{2}\right)$. TGM concentrations in air were determined simultaneously at the 3 REMAP stations and 5 Canadian MDN stations in 1997 and 1998 (Table 1). The REMAP sites collected $24-\mathrm{h}$ integrated 
samples every 6th day (Burke et al., 1995) while the Canadian stations measured continuously (hourly means stored) using the $\operatorname{Tekran}^{\circledR} 2537 \mathrm{~A}$ automated sampler (Blanchard et al., 2002; Poissant et al., 2004; Environment Canada, 2004). Because the RGM component of TGM is small (see below) GEM was assumed equal to measured TGM for this analysis.

TGM concentrations varied seasonally, with winter and spring values higher than summer and fall values (cf. Poissant, 2000; Blanchard et al., 2002). TGM concentrations were significantly different among the US sites (ANOVA, $p<0.0001$ ) with the annual means significantly different between each site (Tukey-Kramer HSD), indicating a south-to-north or urban-to-rural trend. There were also significant differences between the Canadian stations (ANOVA, $p=0.0002$ ), with Egbert and St. Anicet having higher concentrations than all others, and Kejimkujik and St. Andrews having lower concentrations than all others (Tukey-Kramer HSD). These differences reflect both urban-to-rural and west-to-east concentration gradients (Kellerhals et al., 2003).

Analysis of covariance of seasonal mean TGM, with the seasonal average precipitation mercury concentration as the covariate and season as the main effect, revealed a relation between TGM and precipitation mercury concentration $\left(r^{2}=0.48\right.$, $p=0.007, n=26$, East Providence excluded as an outlier, Fig. 3). When restricted to the Canadian network, the same model explained $64 \%$ of the variance. The lower amount of variance explained when all stations are pooled may result, in part, from differing regional gradients, as well as from differences in the network sampling methods. The positive correlation between seasonal mean TGM and precipitation-weighted mercury concentrations may indicate a dependence of precipitation mercury concentrations on vapor-phase mercury, or at least a correlation between oxidized mercury and total mercury in the atmosphere. The residuals of this effect were lower in summer and higher in winter, indicating greater mercury oxidation and scavenging rates in summer (Lin and Pekonen, 1999) and/or increased winter anthropogenic emissions compared to summer (Blanchard et al., 2002). The joint US-Canadian model (Fig. 3) formed the basis for estimating regional TGM concentrations.

Reactive gaseous mercury was not measured by any network. Recent studies suggest that RGM can represent $1-3 \%$ of TGM at continental sites (Lindberg and Stratton, 1998; Landis et al., 2002; Poissant et al., 2004). Because RGM is highly reactive and rapidly scavenged by moist particles and surfaces, RGM concentrations likely fall off rapidly with distance from their primary sources, incinerators, and power plants (Lindberg and Stratton, 1998). Poissant et al., (2004) provided evidence that local oxidation of GEM to RGM occurs at non-marine sites. Thus, RGM concentrations are likely to be highly variable and related to both point sources and oxidant levels. Estimation of the effect of point sources and oxidant levels on the spatial distribution of RGM in the
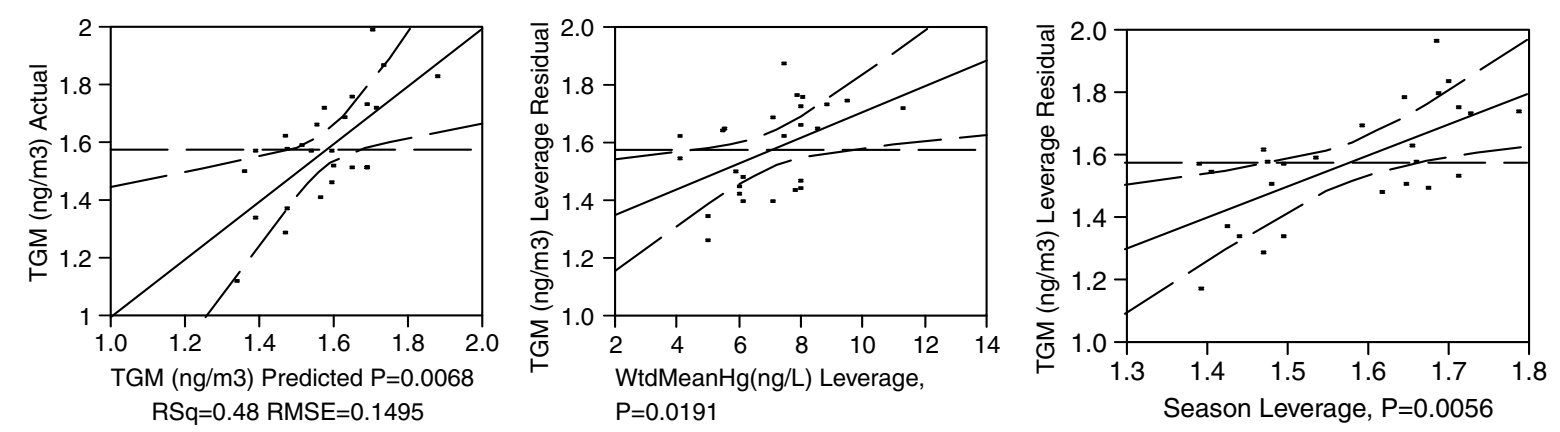

Figure 3. Analysis of covariance model for TGM concentrations at 2 US and 5 Canadian stations. The precipitation amount weighted $\mathrm{Hg}$ concentration was the covariate and season was the main effect. Seasonal mean TGM concentrations were positively correlated with seasonal mean volume-weighted precipitation $\mathrm{Hg}$ concentrations $(p=0.019)$. There was a significant effect of season $(p=0.006)$ with strong leverage. The seasonal means ranked as follows: spring $\left(1.69 \mathrm{ng} \mathrm{m}^{-3}\right)$, winter $(1.65)$, summer $(1.52)$, and fall (1.43). If the US stations which used every 6th-day sampling rather than continuous sampling are dropped from the analysis the percent variance explained by the model increases to $64 \%$. 
atmosphere was beyond the scope of this study. For the purpose of providing bounded estimates of total mercury deposition, we estimated RGM deposition for the region assuming RGM represents $1 \%$ of TGM.

\section{Atmosphere-land surface transfers of mercury}

The exchange of mercury between the atmosphere and ecosystems is bidirectional (e.g. Lee et al., 2000). Precipitation, dry particle, RGM, and GEM deposition contribute mercury to landscape burdens. Oxidized forms of mercury in soils, soil waters, surface waters and aquatic sediments are reduced by both biotic and abiotic processes to form $\mathrm{Hg}^{0}$. Because $\mathrm{Hg}^{0}$ is sparingly soluble in water, most of the $\mathrm{Hg}^{0}$ produced in terrestrial and aquatic systems is partitioned into the vapor phase and reemitted to the atmosphere. For example, Poissant et al. (2004b) presented a summer mercury budget based on measurements in the Baie Saint Francois wetlands (Québec): dew deposition $\left(\sim 0.1 \mathrm{ng} \mathrm{m}^{-2} \mathrm{~h}^{-1}\right)<$ precipitation deposition $\left(\sim 0.68 \mathrm{ng} \mathrm{m}^{-2} \mathrm{~h}^{-1}\right)<$ dry deposition (2.8 $\left.\mathrm{ng} \mathrm{m}^{-2} \mathrm{~h}^{-1}\right)$ for a total bulk deposition of $3.6 \mathrm{ng} \mathrm{m}^{-2} \mathrm{~h}^{-1}$. In comparison, evasion from water $\left(0.5 \mathrm{ng} \mathrm{m}^{-2} \mathrm{~h}^{-1}\right)<$ evasion from soil $\left(0.83 \mathrm{ng} \mathrm{m}^{-2} \mathrm{~h}^{-1}\right)<$ evasion from plant canopy $\left(15 \mathrm{ng} \mathrm{m}^{-2} \mathrm{~h}^{-1}\right)$ for a total evasion term of $\sim 16.3 \mathrm{ng} \mathrm{m}^{-2} \mathrm{~h}^{-1}$. During this short study, bulk evasion was about 4.5 times larger than bulk deposition. The accumulated landscape burden, bioavailability, and persistence of mercury in the environment are all affected by the balance of mercury deposition and reemission. The primary controls on $\mathrm{Hg}^{0}$ (GEM) emissions from different landscape elements are just beginning to be understood and explicit modeling of GEM reemission processes remains problematic. However, we developed an empirical method to estimate the net GEM deposition to forest canopies (net of canopy assimilation and reemission) using foliar mercury accumulation rates. The emission of GEM from soils and surface waters was not modeled in this study.

\section{Precipitation}

We estimated the spatial distribution of mercury deposition due to precipitation by multiplying the seasonal average precipitation mercury concentration fields (described above) by the seasonal 30-year average (1971-2000) precipitation fields derived from NOAA and Environment Canada climatic data (1302 sites). Seasonal regression models were developed to extract the local orographic component of the variance in seasonal precipitation. The residuals of this model were spatially interpolated to provide local estimates of medium-scale orographic and moisture source effects (c.f. Dingman, 1981). The regression models were then applied to a $100-\mathrm{m}$ resolution digital elevation model (DEM) and combined with the residual field to provide a localized estimate of seasonal precipitation rate.

\section{Cloud-water deposition}

The cloud-water deposition model of Miller et al. (1993a, b) was parameterized with representative canopy configurations for the major surface types expected to receive cloud-water deposition. Sensitivity analyses were conducted with the multi-layer model in order to characterize model response to a large set of possible canopy by meteorological condition interactions. We then statistically apportioned the multi-layer model response to key environmental parameters that can be estimated for each $100-\mathrm{m}$ pixel (wind speed, temperature, cloud frequency, leaf area index (LAI)). For example, summer (leaves on) cloud-water input to a mixed forest canopy can be estimated as follows:

$$
\begin{aligned}
\mathrm{cm} \text { cloud }= & \left(-0.0701+0.0836^{*} \mathrm{cf}\right. \\
& +8.903 \times 10^{-3^{*}} \mathrm{cf}^{2}-1.1946 \times 10^{-4^{*}} \mathrm{cf}^{3} \\
& \left.+6.767 \times 10^{-7^{*}} \mathrm{cf}^{4}\right) *\left(\left(0.14019^{*} \mathrm{ws}\right)\right. \\
& +0.38051)^{*}\left(1.006-\left(0.0004946^{*} \mathrm{~T}\right)\right) \\
& *(\mathrm{pLAI} / 5.7)
\end{aligned}
$$

where $\mathrm{cf}=$ cloud frequency $(\%)$, ws $=$ mean wind speed $\left(\mathrm{m} \mathrm{s}^{-1}\right), \mathrm{T}=$ mean temperature $\left({ }^{\circ} \mathrm{C}\right)$, and $\mathrm{pLAI}=$ projected leaf area $\left(\mathrm{m}^{2} \mathrm{~m}^{-2}\right)$. Similar equations were developed for different receptor surfaces.

Cloud frequency was taken to be a function of elevation as observed at Whiteface Mountain, NY (Miller et al., 1993b) and adjusted for regional variation in atmospheric water vapor content using the ratio of precipitation rate at a given location relative to the value at Whiteface Mountain. 
Because cloud liquid water content (LWC) is related to cloud frequency (Miller and Friedland, 1999) we formulated Equation 2 such that the cloud-frequency term includes the effect of LWC. We did not make spatial estimates of coastal-fog water deposition because of the lack of adequate data on coastal fog frequency and LWC. Coastal fog was estimated to contribute between $1.6 \%$ and $16 \%$ of total water deposition at the immediate coast of Nova Scotia and Newfoundland (Beauchamp et al., 1998) although fog LWC and fog-water deposition likely fall off rapidly inland.

\section{Dry deposition of $\mathrm{Hg}_{p}$ and $\mathrm{RGM}$}

Dry deposition of $\mathrm{Hg}_{\mathrm{p}}$ and RGM were estimated using the approach of Lindberg et al. (1992) with some differences and additions described below. Dry-deposition velocities for aerosol particles and gasses were estimated using a big-leaf model designed for complex terrain and multi-species canopies (Miller et al., 1993a, b). This model includes appropriate physics to simulate deposition to a complex landscape with a wide range of elevations, pressures, temperatures, and receptor surface types. A big-leaf model is preferred over a multi-layer model for this application because of the limited information available to properly characterize the receptor surface at each 100-m pixel. Estimation of receptor-surface characteristics is described below.

Seasonal mean wind speed for elevations less than $600 \mathrm{~m}$ elevation were generalized from a NOAA (1998) national summary of the period 1930-1996. Wind speeds recorded at CASNET stations were consistent with the NOAA observations. The wind-speed increase with elevation was modeled following Miller et al. (1993b). Thirtyyear average (1971-2000) mean monthly temperatures were derived from observations at 986 well-distributed monitoring stations in the Northeastern US and Eastern Canadian Provinces by NOAA and EC. Seasonal mean temperatures were formed from the monthly means. A multiple regression model of mean temperature as a function of season, latitude, longitude, and elevation explained $94 \%$ of the variance in these data.

Representative seasonal averages of hourly time-series data describing the diurnal fluctuations about the seasonal daily means for temperature, wind speed, and relative humidity, were derived from observations at CASTNET (2004) stations. The average percentage of possible solar radiation received was calculated from global-irradiance measurements made at these sites. The representative diurnal fluctuations about the daily mean were applied to seasonal mean microclimate values estimated for each grid cell to produce seasonal average representations of the diurnal cycle in driving variables for the deposition model. The spring and fall model runs were broken into leaves-on and leaves-off periods, with meteorological conditions averaged independently for each sub-seasonal period.

Dry deposition to water surfaces was calculated following the method of $\mathrm{Xu}$ et al. (1999). RGM was assumed to behave similarly to nitric acid vapor (Rea et al., 2001; Lindberg et al., 1992).

Net GEM deposition inferred from mercury accumulation in foliage and leaf fall rates

Various, largely unsatisfactory, approaches have previously been used to estimate GEM dry deposition. The Lindberg et al. (1992) model clearly overestimates GEM deposition (S.E. Lindberg, personal communication, 2002) because it does not include a compensation point for mercury (Hanson et al., 1995) as is necessary for modeling atmospheric species with bi-directional fluxes (e.g. van Hove et al., 2002) and it lacks representation of canopy emission of GEM (Lindberg et al., 1998; Lindberg and Meyers 2001; Lindberg et al., 2002). $\mathrm{Xu}$ et al. (1999) side-stepped modeling a compensation point by separately calculating GEM deposition according to Lindberg et al. (1992) and formulating a separate model for canopy emission of GEM consistent with the very limited (pre1999) understanding of controls on this process. Net GEM deposition was taken to be the net of the two model results. Unfortunately, several key parameters in $\mathrm{Xu}$ et al. (1999) canopy emission model - such as the supersaturated concentration of $\mathrm{Hg}^{0}$ dissolved in soil water - remain highly uncertain, are likely quite variable, and are difficult to model with available information. In addition, recent experimental evidence (Johnson et al., 2003) indicates that soil emission of $\mathrm{Hg}^{0}$ is not limited by diffusion through soil as was previously thought (see Johnson and Lindberg 1995; Lindberg et al., 1998) and, therefore, supersaturation of soil water with dissolved gaseous $\mathrm{Hg}^{0}$ as assumed by $\mathrm{Xu}$ 
et al. (1999) and Bash et al. (2004) appears unlikely. Recent measurements of GEM emission from vascular plant canopies suggest that some biological process (bioreduction) at the root-soil interface may be responsible for the production of and apparent supersaturation of $\mathrm{Hg}^{0}$ in the xylem of plants exhibiting net GEM emission (Lindberg et al. 2002).

Rea et al. (2002) measured mercury in the foliage of deciduous trees over the course of the growing season and found that total foliar mercury accumulation was substantially less than GEM deposition estimated following Lindberg et al. (1992). Rea et al. (2001) determined that $\mathrm{Hg}_{\mathrm{p}}$ and $\mathrm{RGM}$ dry deposition are rapidly washed off foliar surfaces, and, therefore, foliar accumulation of mercury most likely represents GEM assimilation. In controlled pot and chamber studies with aspen, Ericksen et al. (2003) determined that all foliar accumulation of mercury resulted from vapor uptake, regardless of soil mercury concentration.

Developing an inferential model for GEM deposition is difficult because of the lack of information on the physiological and biochemical controls responsible for $\mathrm{Hg}^{0}$ assimilation by foliage. There is no obvious mechanism to bind and store $\mathrm{Hg}^{0}$ entering the mesophyll through the stomata. One possible mechanism might involve $\mathrm{Hg}^{0}$ first being oxidized to $\mathrm{Hg}^{2+}$ (within the plant) before it can be bound by phytochelatin molecules and sequestered in the vacuole space (Cobbett, 2000). During periods of photosynthesis, free radicals would be available to complete this oxidation.

The rate of mercury accumulation in foliage was highly linear with no significant difference between accumulation rates measured by Rea et al. (2002) in two widely separated forests, in two different years, with significantly different meteorological conditions and modeled GEM deposition velocities at each site (Fig. 4). The lack of difference in foliar accumulation rates between the two sites given the difference in deposition velocities estimated using the Lindberg et al. (1992) approach (Rea et al., 2002) suggests that foliar mercury accumulation might be limited by biological processes mediating sequestration of mercury.

Given the very likely possibility that the annual transfer of mercury from foliage to forest floor via leaf fall represents net GEM deposition (Grigal, 2002; Rea et al., 2002; Ericksen et al., 2003), we

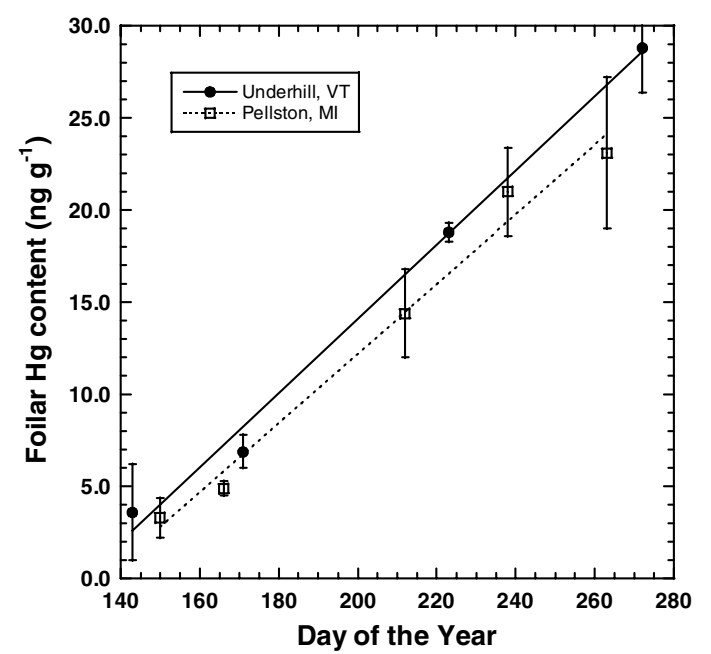

Figure 4. Growing season mercury accumulation in foliage of various deciduous species measured in Vermont and Michigan by Rea et al. (2001). Hg accumulation was highly linear with similar daily accumulation rates at both sites. Points are collection period means (with standard errors) of various species.

developed an empirical method to estimate the accumulation of mercury in foliage of the study area. Observed mercury contents in foliage at Underhill, VT (Rea et al., 2002) are described well by

$$
\mathrm{Hg}_{\text {foliage }}\left(\mathrm{ng} \mathrm{g}^{-1}\right)=\mathrm{DOY}^{*} 0.20137-26.203
$$

$\left(r^{2}=0.99, \quad p<0.0001, n=4, \quad\right.$ DOY $=$ day of year). Foliar mercury accumulation was also linear with a similar accumulation rate (slope of Equation 3) at the Pellston, MI site studied by Rea et al. (2002) (Fig. 4). The zero Hg intercept of Equation 3 indicates the onset of accumulation occurred on day 130 (May 10th) at the Underhill site $(44.53 \mathrm{~N})$ and 5 days later at the Pellston site $(45.57 \mathrm{~N})$, both plausible dates for initial swelling of buds at these locations. The mercury accumulation period constitutes the time between the zero $\mathrm{Hg}$ intercept and majority leaf fall, and amounts to 140 (Pellston) to 150 (Underhill) days at these two sites, approximating the length of the growing season. The accumulation period was both shorter and the total mercury accumulation less at the more northerly Pellston site. As a first approximation we expect the mercury content of deciduous foliage to be a linear function of growing season length.

We analyzed growing season length and mean annual temperature (MAT) from stations in New 
England. In this region, the length of the growing season was extended by 6.2 days for each $1{ }^{\circ} \mathrm{C}$ increase in $\operatorname{MAT}\left(r^{2}=0.77, p<0.0001, n=28\right)$. This result falls between the estimate by White et al. (1999) of an increase of 5 days per $1{ }^{\circ} \mathrm{C}$ MAT derived for stations between 32.8 and $45.5 \mathrm{~N}$ in the eastern US and a value of 9.6 days per $1{ }^{\circ} \mathrm{C}$ we calculated from Canadian data (CANSIS 2002) representing $\quad 43.73-46.94 \mathrm{~N}, \quad 63.29-73.69 \mathrm{~W}$ $\left(r^{2}=0.95, p<0.0001, n=38\right)$ and, therefore, seems to be an appropriate generalization for the study region. Using the Underhill site as the basis (30year MAT $=10.75^{\circ} \mathrm{C}$ ), the mercury foliar accumulation period is then

Accumulation Period $=83.4+6.2^{*}$ MAT.

The geographic distribution of MAT was modeled as a function of latitude, longitude and elevation using data from NOAA and Environment Canada stations with 10 years or more of record $\left(r^{2}=0.95, p<0.00001, n=981\right)$.

In controlled greenhouse fumigation studies Gustin et al. (2003) found that foliar GEM uptake was a linear function of air concentration. We used their data to compute a linear adjustment based on GEM concentration to the foliar accumulation rate determined from the field studies. The concentration of mercury representative of the major deciduous species of the study area (see Rea et al., 2001) at the end of the growing season was calculated as

$$
\begin{aligned}
& \mathrm{Hg}_{\text {foliage }}\left(\mathrm{ng} \mathrm{g}^{-1}\right) \\
&= 0.20137^{*} \text { Accumulation Period } \\
&+4.71^{*}(\mathrm{TGM}-1.37)
\end{aligned}
$$

We also estimated the mercury accumulation in foliage of evergreen species that retain needles for 2-7 years and exhibit continued accumulation of mercury in the years after foliage formation (Rasmussen, 1995; Grigal, 2002). Evergreen foliage generally exhibits higher mercury concentrations than deciduous foliage from the same site due to the longer needle life span of evergreens (Rasmussen, 1995; Grigal, 2002). Rasmussen (1995) found that the mercury concentration of balsam fir and white spruce needles increased by 5-10 ng $\mathrm{g}^{-1}$, during the year after foliage formation. We assume that evergreens accumulate mercury at the same rate as deciduous foliage during the first year and increase by $10 \mathrm{ng} \mathrm{g}^{-1}$ for each subsequent year of needle retention.

The flux of mercury to the forest floor is computed from the estimated foliar mercury concentration at senescence and an estimate of leaf-fall mass. Leaf-fall mass is proportional to total productivity and related to climate at continental to global scales (Schlesinger, 1977). However, in a sample of New England forests we conducted, foliar biomass was primarily related to basal area of the plot (age and other growth factors) and forest type $\left(r^{2}=0.73, p<0.0001, n=210\right)$, and only weakly related to temperature and precipitation (Table 2). Within the northeast region, variance in standing biomass and production is dominated by stand age (management history) rather than climatic factors. Because it is currently impossible to estimate forest age at the spatial resolution of the model, we used the mean foliage biomass (adjusted for evergreen needle retention) modified by climate to estimate litter fall mass by forest type (Table 2).

Landscape and receptor surface characterization A $100-\mathrm{m}$ resolution digital elevation model was derived from the USGS National Elevation Data Set (NED) (Gesch et al., 2002) and Shuttle Radar

\begin{tabular}{|c|c|c|c|c|c|c|c|c|}
\hline \multirow[t]{2}{*}{$\begin{array}{l}\text { Land } \\
\text { Cover }\end{array}$} & \multirow{2}{*}{$\begin{array}{l}\text { Mean Standing } \\
\text { Leaf Biomass } \\
\left(\mathrm{MT} \mathrm{ha} \mathrm{ha}^{-1}\right)\end{array}$} & \multirow[t]{2}{*}{$\begin{array}{l}\text { Standard } \\
\text { Deviation }\end{array}$} & \multirow[t]{2}{*}{$\begin{array}{l}\text { Annual Leaf } \\
\text { fall Yield }\left(\mathrm{g} \mathrm{g}^{-1}\right)\end{array}$} & \multirow[t]{2}{*}{$\begin{array}{l}\text { Leaf } \\
\text { Area }\left(\mathrm{m}^{2} \mathrm{~g}^{-1}\right)\end{array}$} & \multicolumn{2}{|c|}{$\begin{array}{l}\text { Climate Dependence Regres- } \\
\text { sion Models }\end{array}$} & \multirow[t]{2}{*}{$\begin{array}{l}\text { Temperature } \\
\left(\text { MT ha }{ }^{-1}{ }^{\circ} \mathrm{C}^{-1}\right)\end{array}$} & \multirow[t]{2}{*}{$r^{2}$} \\
\hline & & & & & $\begin{array}{l}\text { intercept } \\
\left(\mathrm{MT} \mathrm{ha}^{-1}\right)\end{array}$ & $\begin{array}{l}\text { Precipitation } \\
\left(\mathrm{MT} \mathrm{ha}^{-1} \mathrm{~cm}^{-1}\right)\end{array}$ & & \\
\hline Deciduous & 3.7 & 1.5 & 1 & 0.0192 & 2.60 & 0.043025 & -0.28834 & 0.10 \\
\hline Evergreen & 3.1 & 1.9 & 0.25 & 0.0113 & -5.94 & 0.082690 & ns & 0.25 \\
\hline Mixed & 4.6 & 2.7 & 0.625 & 0.0150 & 5.75 & 0.058897 & -0.66828 & 0.21 \\
\hline
\end{tabular}
Topography Mission data for Canada (National

Table 2. Characteristics of regional forest types used in the dry deposition and leaf fall mercury accumulation models

$\mathrm{MT}=$ metricton, $\mathrm{ns}=$ not significant. 
Aeronautics and Space Administration, 2004). Slope and aspect (used in solar radiation and microclimate calculations) were calculated from the DEM. The US National Land Cover Data (NLCD) and EC AVHRR-derived land-cover data were used as the basis for receptor surface characterization. The NLCD differentiates 21 land cover types, including 3 forest types: evergreen, deciduous, and mixed forest at an approximate 30$\mathrm{m}$ ground resolution (Vogelmann et al., 2001). The EC product differentiates 13 land-cover classes, including evergreen, deciduous, and mixed forest, at $1-\mathrm{km}$ resolution. Receptor surface characteristics for the forest classes are given in Table 2.

\section{Results and discussion}

Total estimated mercury deposition - the sum of precipitation-delivered mercury, GEM assimila- tion by vegetation, RGM and dry-aerosol deposition, and cloud-droplet interception - exhibited complex spatial variance at a range of spatial scales (Fig. 5). Total deposition ranged an order of magnitude from approximately $3 \mu \mathrm{g} \mathrm{m}^{-2} \mathrm{y}^{-1}$ in barren areas of the north to greater than $30 \mu \mathrm{g} \mathrm{m}^{-2} \mathrm{y}^{-1}$ in the southwest and on isolated high mountain summits with heavy cloud-water deposition. The majority of deposition occurs from late spring through early fall (see also Van Arsdale et al. 2005). This is due to several factors including increased oxidant levels in the atmosphere creating more $\mathrm{Hg}^{2+}$ and RGM that can be dry deposited or scavenged by cloud and rain droplets during moist conditions (Fig. 1). Terrestrial plants expand and grow their leaves during this period, altering receptor surface conditions to promote efficient RGM and GEM dry deposition (e.g. Lindberg et al., 2002; Poissant et al., 2004).

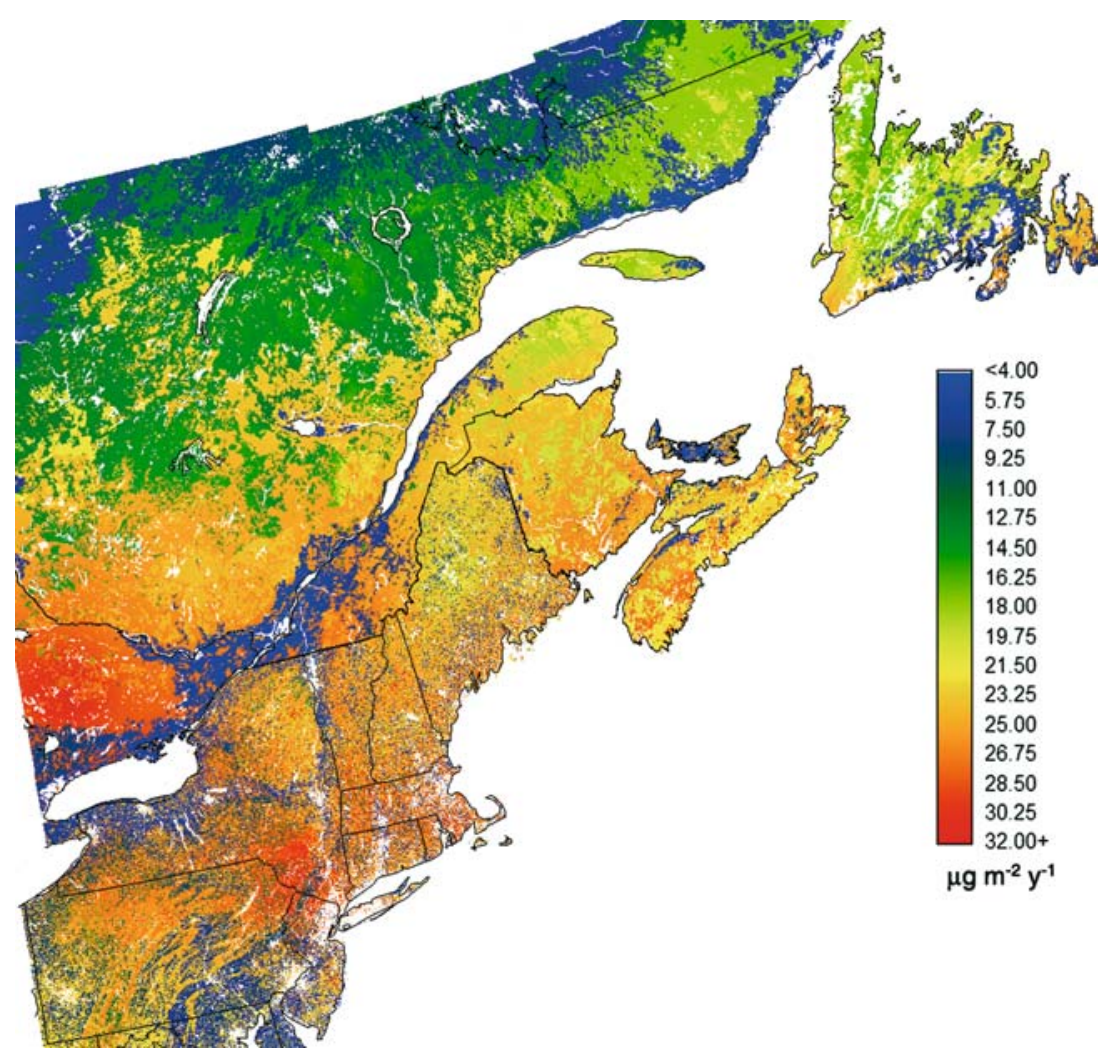

Figure 5. Estimated total mercury deposition (wet + dry) in $\mu \mathrm{g} \mathrm{m}^{-2} \mathrm{y}^{-1}$ to rural areas. Deposition was not estimated for areas with urban or residential land cover. Mercury deposition is likely to be much greater than depicted here in the immediate vicinity of urban areas and emissions sources. The effects of urban and point emissions sources are not well captured by the sparse, rural mercury observation network. Mercury deposition may be greater than depicted here in the northern low arctic areas because of seasonal mercury depletion events (Lindberg et al., 2002). 
Precipitation, RGM and GEM dry deposition each contribute about a third of the total estimated mercury deposition (Table 3). Particulate deposition generally accounted for less than $1 \%$ of total deposition. Cloud-water deposition was generally unimportant except for areas above $1000 \mathrm{~m}$ elevation. At the highest elevations, cloud-water inputs may account for up to one-half of total mercury deposition. Precipitation tends to dominate mercury deposition in the non-forested landscape. Because the land cover of most jurisdictions is predominantly forest (Table 3) the dry deposition modes are likely to be very important.

Effort and resources should be placed into establishing a network for measuring the atmospheric concentrations and fluxes of RGM and GEM. There is likely substantial spatial variation in atmospheric RGM and $\mathrm{Hg}_{\mathrm{p}}$ concentrations related to proximity to emission sources that we are unable to characterize in this analysis. Hence, we have a low confidence in the specificity of the RGM and $\mathrm{Hg}_{\mathrm{p}}$ deposition estimates presented here (due to the lack of measurements). However, they are likely of the correct order of magnitude. The modeled deposition velocities and corresponding fluxes of $\mathrm{Hg}_{\mathrm{p}}$ and $\mathrm{RGM}$ were consistent with values reported by other investigators using the Lindberg et al. (1992) approach to modeling dry deposition. The magnitude of the RGM + $\mathrm{Hg}_{\mathrm{p}}$ flux can also be judged from the many studies of mercury in canopy throughfall waters in the literature. Most investigators found that throughfall was enriched in mercury relative to wet deposition by a ratio of $1: 1$ to $3: 1$ (Grigal, 2002). The additional mercury in throughfall is thought to be due to the $100 \%$ wash off efficiency of RGM and mercury-containing aerosols (Rea et al., 2002; Ericksen et al., 2003). Our estimate of a model throughfall (wet deposition $+\mathrm{RGM}+\mathrm{Hg}_{\mathrm{p}}$ ) to wet depositon ratio ranges from 1.25:1 (10th percentile) to $3.60: 1$ (90th percentile) with a median value of 2.05:1. We have higher confidence in the GEM deposition estimates as they are consistent with the leaf fall studies of many investigators (cf. Grigal, 2002) and derived from direct observations in the study area. Therefore, the present wetdeposition network is probably measuring only one-third to one-half of the total mercury flux.

The spatial complexity of the deposition field is created by atmospheric composition, meso- and micro-climate, and receptor surface patterns. Clear regional gradients in atmospheric mercury concentrations were evident. Seasonal precipitation-weighted mean mercury in the liquid phase decreased markedly with increasing latitude (Fig. 1). Superimposed on the south-north gradient are the effects of urban and industrial centers (Fig. 2). Areas downwind from urban centers such as coastal Maine also exhibit elevated liquid phase concentrations (Fig. 2, VanArsdale et al. 2005). Complex patterns in precipitation rates driven by meso-scale circulation and local orographic effects

Table 3. Summary of mercury deposition rates $\left(\mu \mathrm{g} \mathrm{m}^{-2} \mathrm{y}^{-1}\right)$ by jurisdiction

\begin{tabular}{lllllllll}
\hline State/Province & Total & CV $(\%)$ & Precipitation & GEM & RGM & Particle & Cloud & Forest (\%) \\
\hline Connecticut & 16.7 & 69 & 4.8 & 5.7 & 6.0 & 0.23 & 0.000 & 58 \\
Massachusetts & 16.8 & 72 & 4.6 & 5.7 & 6.2 & 0.30 & 0.002 & 59 \\
Maine & 19.5 & 42 & 4.4 & 6.7 & 8.1 & 0.40 & 0.007 & 80 \\
New Brunswick & 21.9 & 28 & 4.3 & 7.2 & 10.0 & 0.50 & 0.002 & 93 \\
Newfoundland & 10.5 & 78 & 3.7 & 2.1 & 4.4 & 0.30 & 0.007 & 51 \\
New Hampshire & 21.1 & 41 & 5.8 & 7.4 & 7.5 & 0.38 & 0.058 & 81 \\
New Jersey & 13.5 & 85 & 4.0 & 3.5 & 5.5 & 0.43 & 0.000 & 44 \\
Nova Scotia & 19.5 & 45 & 4.3 & 5.9 & 8.9 & 0.49 & 0.001 & 81 \\
New York & 18.4 & 55 & 6.1 & 6.1 & 5.9 & 0.33 & 0.012 & 63 \\
Pennsylvania & 18.8 & 47 & 7.2 & 5.7 & 5.5 & 0.33 & 0.006 & 65 \\
Price Edward I & 10.7 & 92 & 2.7 & 2.8 & 5.1 & 0.20 & 0.000 & 36 \\
Québec & 13.2 & 66 & 4.8 & 3.5 & 4.7 & 0.25 & 0.016 & 68 \\
Rhode Island & 16.7 & 73 & 4.0 & 5.9 & 6.5 & 0.27 & 0.000 & 60 \\
Vermont & 19.9 & 47 & 6.1 & 7.0 & 6.4 & 0.25 & 0.017 & 73 \\
\hline
\end{tabular}

The percentage area covered by forest in each jurisdiction is provided to illustrate the significance of the forested receptor surface in driving GEM, RGM, and total mercury deposition. The magnitude of spatial variation in the deposition rate within each jurisdiction is characterized by the coefficient of variation $(\mathrm{CV})$ of the total mercury deposition. 
cause large meso- and local-scale variations in wet deposition of mercury within regions of similar liquid phase mercury concentrations (Fig. 6). Areas of relatively low precipitation mercury concentration (see Fig. 2) frequently experience relatively high rates of precipitation mercury deposition (see Fig. 6) driven by high precipitation rates.

Variance in receptor surface conditions such as the presence or absence of forest and the type of forest had a large impact on the magnitude of the estimated dry deposition fluxes. The temperate and boreal forests of the region have very high leaf areas (Table 2) providing a large surface area for deposition. Evergreen forests assimilate more GEM per gram of foliage than deciduous forests because of their long leaf life spans. New Brunswick, New Hampshire, and Vermont exhibited the highest, whereas Prince Edward Island and Newfoundland exhibited the lowest total deposition rates reflecting the complex interaction of patterns in atmospheric mercury concentrations, meso-scale climate, and receptor surface differences. Pennsylvania and New Jersey had some of the highest precipitation concentrations of mercury (Table 1, Fig. 2), but fell in the mid-range for total deposition largely because of lower percentages of forested area than the New England States and Québec.

Whereas broad regional patterns in forest composition and extent (e.g. more evergreens to the north, greater percentage forested area to the north and northeast) are evident in the dry deposition estimates (Fig. 7), there is also substantial variation in receptor-surface characteristics at the $1-10 \mathrm{~km}$ scale. The effect of local-scale variation in the receptor surface and micro-climate conditions was evident in the frequency distributions of deposition by mode from a series of 212 small

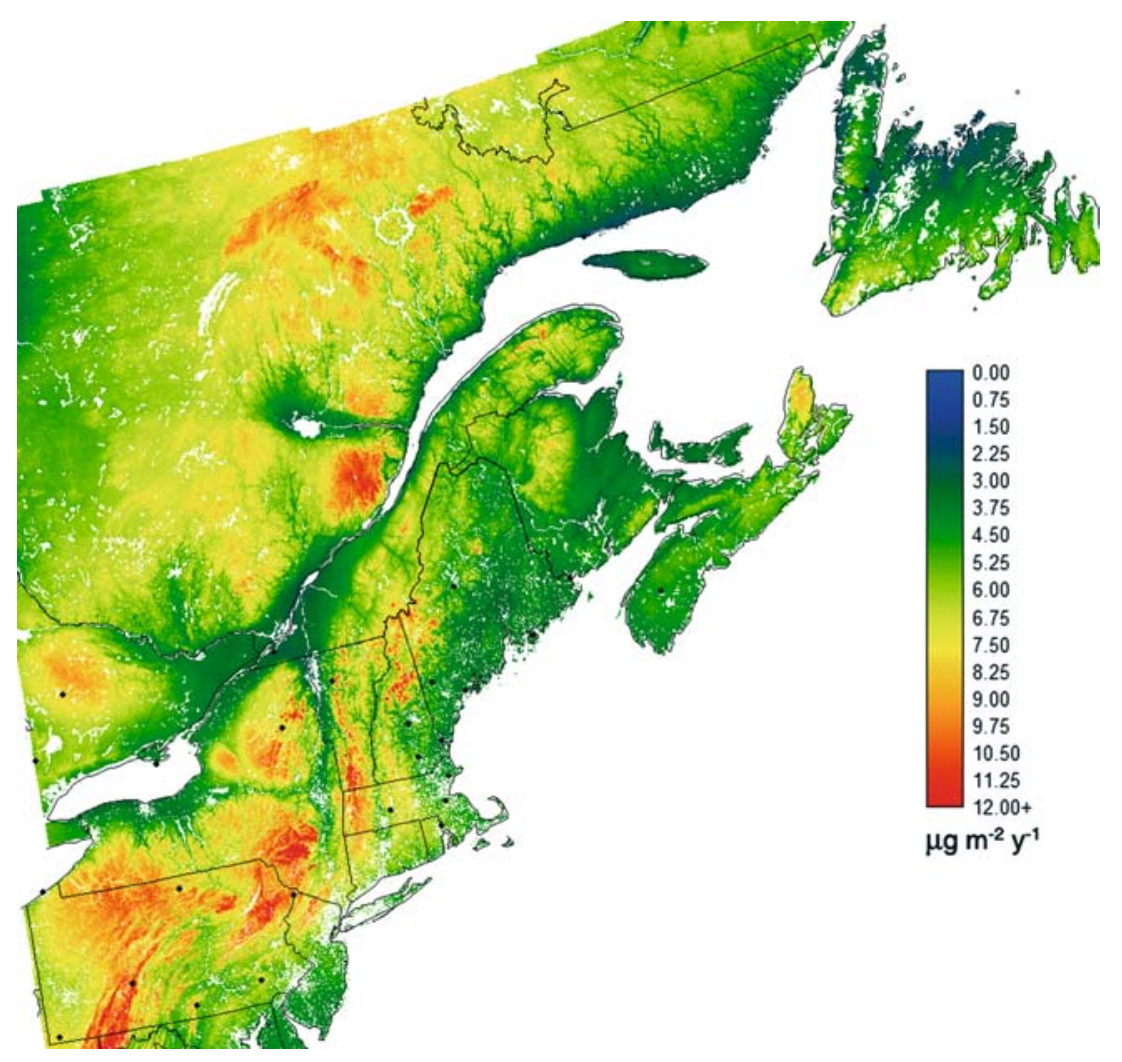

Figure 6. Estimated precipitation mercury deposition in $\mu \mathrm{g} \mathrm{m}^{-2} \mathrm{y}^{-1}$ to rural areas. Deposition was not estimated for areas with urban or residential land cover. Mercury deposition is likely to be much greater than depicted here in the immediate vicinity of urban areas and emissions sources. The effects of urban and point-emissions sources are not well captured by the sparse, rural mercury observation network (black dots). 


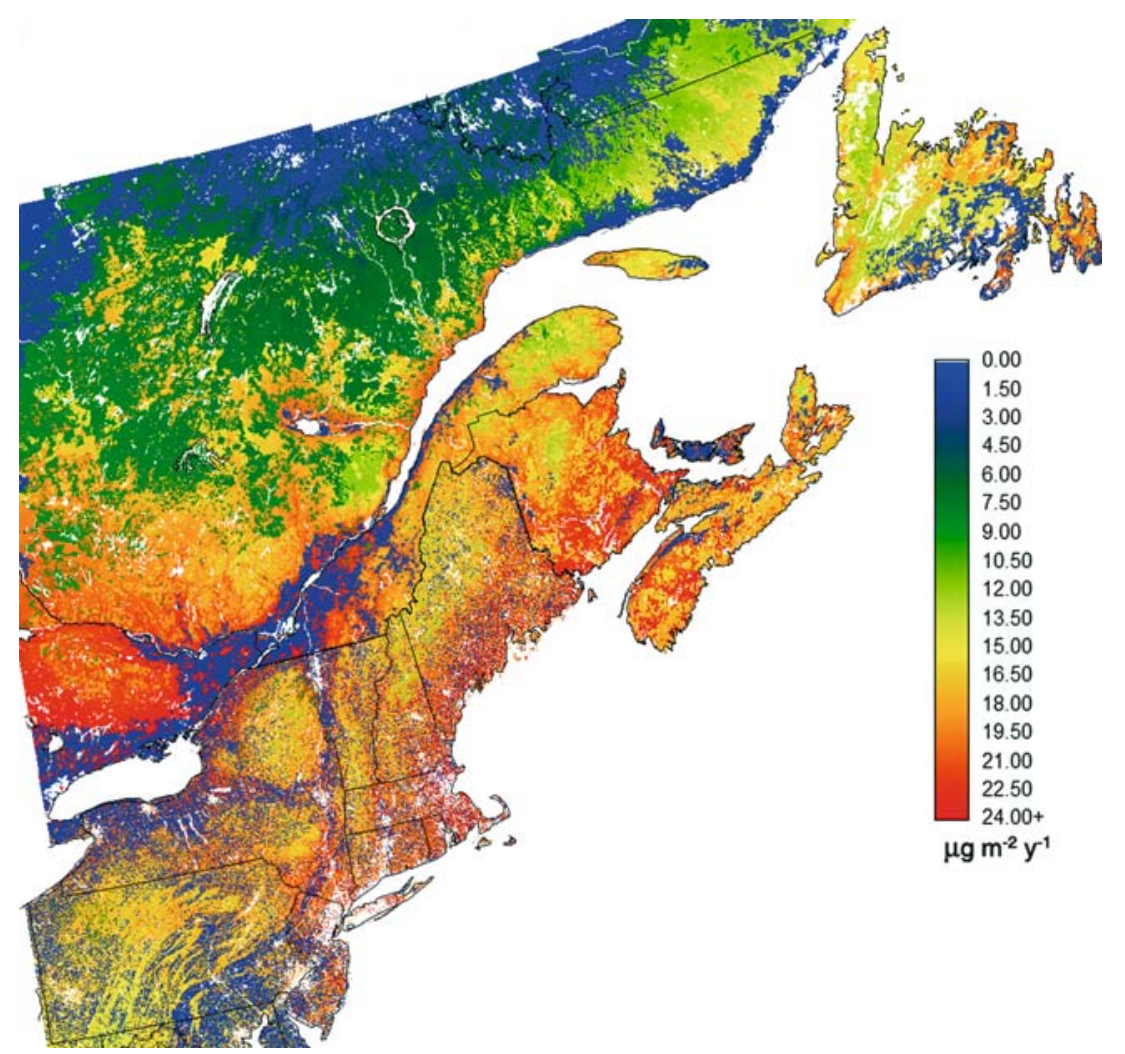

Figure 7. Estimated dry mercury deposition in $\mu \mathrm{g} \mathrm{m}^{-2} \mathrm{y}^{-1}$ to rural areas. Deposition was not estimated for areas with urban or residential land cover. Mercury deposition is likely to be much greater than depicted here in the immediate vicinity of urban areas and emissions sources. The effects of urban and point emissions sources are not well captured by the sparse, rural mercury observation network. Dry mercury deposition may be greater than depicted here in the northern low arctic areas because of seasonal mercury depletion events (Lindberg et al., 2002).

watersheds in New Hampshire and Vermont (Fig. 8). These small watersheds range in size from 3 to 28,674 ha and were randomly selected as part of the USEPA-REMAP lake study (Kamman et al., 2005). Watersheds at this scale, and within a relatively restricted geographic area and range of the overall atmospheric concentration gradient, still exhibited almost the full range of total deposition experienced across the region (Fig. 5). Total deposition was also nearly evenly divided between precipitation, GEM and RGM at this scale with a tendency for GEM deposition to be the most substantial flux (Fig. 8).

Vapor-phase mercury deposition via assimilation into plant foliage may be more important to the bioavailability of mercury than simply accounting for one-third or more of total mercury deposition. In a controlled chamber study,
Ericksen et al. (2003) measured methyl-mercury $(\mathrm{MeHg})$ concentrations in aspen leaves ranging from $2.8 \%$ of total- $\mathrm{Hg}$ in new foliage to $0.3 \%$ of total-Hg in leaves near senescence (average $0.8 \%$ ). Field investigations have found ratios of $\mathrm{MeHg}$ to total- $\mathrm{Hg}$ in leaf litter ranging from $0.4 \%$ in deciduous forest (Scweisig and Matzner, 2000) to $1.8 \%$ in evergreen forest (Lee et al., 2000a, b). It is not yet known if foliar $\mathrm{MeHg}$ represents in situ methylation of atmospheric mercury, direct deposition of $\mathrm{MeHg}$ from the atmosphere, or transport of $\mathrm{MeHg}$ from the soil solution in the xylem stream (Bishop et al., 1998). If this range of $\mathrm{MeHg}$ percentages is broadly representative of conditions in the field (cf. Lee et al., 2000a, b; Scweisig and Matzner, 2000; St. Louis et al., 2001) then our modeling results indicate that on the order of $5-135 \mathrm{ng} \mathrm{m}^{-2} \mathrm{y}^{-1} \mathrm{MeHg}(0.4 \%$ to $1.8 \% \times$ range 

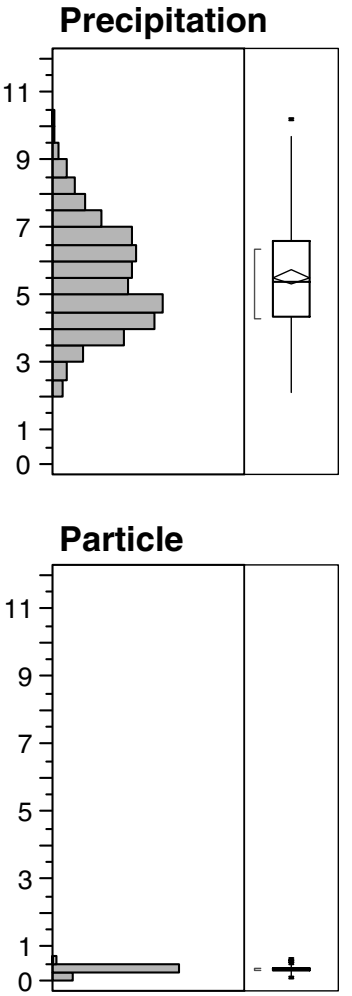

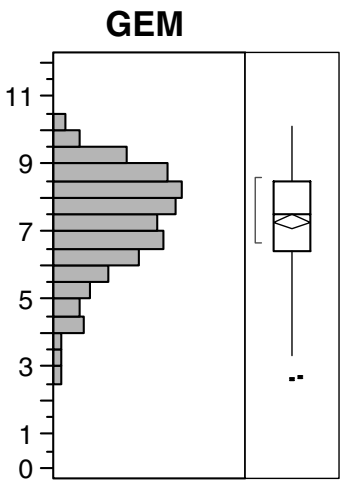

Cloud

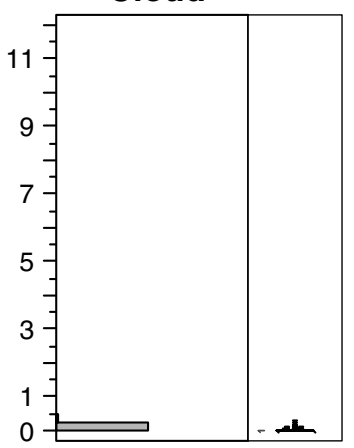

RGM

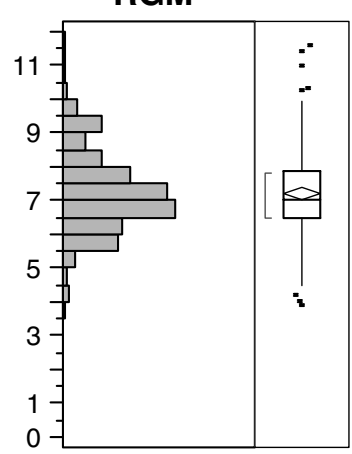

Total

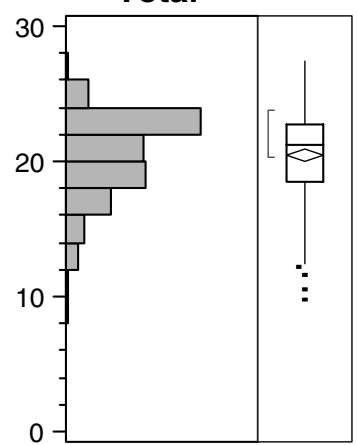

Figure 8. Frequency distributions of mercury deposition by deposition mode and total for 212 small (3-28,674 ha, mean 1193 ha, median $493 \mathrm{ha}$ ) watersheds in Vermont and New Hampshire. Note the scale is the same $\left(0-12 \mu \mathrm{g} \mathrm{m}^{-2} \mathrm{y}^{-1}\right)$ for each of the deposition modes, whereas the scale for total deposition is $0-30 \mu \mathrm{g} \mathrm{m} \mathrm{m}^{-2}$.

of estimated leaf fall mercury flux) is made available to biota from mercury vapor assimilation by foliage. Evergreen and mixed forests would be expected to have the highest $\mathrm{MeHg}$ inputs because of high leaf biomass and high $\mathrm{MeHg}$ :total-Hg ratios. There are numerous insects that feed on plant material, that are eaten by insects, birds or mammals, that may in turn be consumed by large predators. Furthermore, a large portion of stream $\mathrm{MeHg}$ transfers from uplands to aquatic ecosystems are associated with particulate carbon entrained when waters flow over the surface of semi-frozen soil during snowmelt (Scherbatskoy et al., 1998; Shanley et al., 2004). This particulate carbon transport is likely to be leaf litter in various stages of decomposition. The large pool of mercury in leaf litter may also serve as an important source of mercury for methylation in upland environments (Shanley et al., 2004).

To improve understanding of the magnitude and spatial distribution of total mercury deposi- tion monitoring networks for wet and dry deposition need to be created, expanded, standardized, and stabilized (see Mason et al., 2005). The current mixed network is too problematic (multiple collector types and protocols) and unstable (stations being dropped because of lack of funding) to provide good regional coverage and reliable detection of regional-scale temporal trends. The current networks also emphasize rural areas and need to be expanded to better characterize conditions in the urban and near-urban environment. It is imperative that we establish a network for monitoring of GEM and RGM in the United States and expand the TGM network in Canada to include RGM. Measurements of RGM plume transport and dispersion are needed to assess the effects of point sources on dry deposition. Intensive field studies are required to improve our understanding of GEM dry deposition and emission fluxes over a variety of surface types. Establishing a mercury dry-deposition network is essential because this analysis and others 
(cf. Grigal 2002) suggest that RGM and GEM deposition likely represent one-half to two-thirds of the total mercury deposition. Measurements of atmospheric $\mathrm{MeHg}$ concentrations as well as physiological and biochemical studies are needed to determine the sources and mechanisms of $\mathrm{MeHg}$ accumulation in plant foliage.

\section{Acknowledgements}

Financial support for this project was provided by Northeast States for Coordinated Air Use Management (NESCAUM), Environment Canada, the Vermont Agency of Natural Resources, and the US-EPA REMAP Program. Environment Canada-CAMNet provided TGM data. NOAA and Environment Canada provided climate data. We thank the investigators, operators and laboratory personal of the MDN, USGS, and EPA/NESCAUM-REMAP networks for their outstanding work conducting demanding measurements of atmospheric mercury concentrations and deposition. We thank S Lindberg, M. Gustin, and L. Alter for stimulating conversations. J. Shanley, K. Robbinson and two anonymous reviewers made many helpful contributions to the manuscript.

\section{References}

Alter, L. (2000). Mercury Deposition and Atmospheric Concentrations in New England: Year 1 Data and Quality Assurance Report to Ray Thompson, REMAP Coordinator, USEPA, New England Region. North East States for Coordinated Air Use Management, Boston, MA.

Bash, J.O., Miller, D.R., Meyer, T.H. and Bresnahan, P.A. (2004). Northeast United States and Southeast Canada natural mercury emissions estimated with a surface emission model. Atmos. Environ. 38, 5683-92.

Beauchamp, S., Torden, R. and Pinette, A. (1998). Chemistry and deposition of acidifying substances by marine advection fog in Atlantic Canada. Proceedings of the 1st International Conference on Fog and Fog Collection. Vancouver Canada..

Blanchard, P., Froude, F.A., Martin, J.B., Dryfhout-Clark, H. and Woods, J.T. (2002). Four years of continuous total gaseous mercury (TGM) measurements at sites in Ontario, Canada. Atmos. Environ. 36, 3735-43.

Burke, J., Hoyer, M., Keeler, G. and Scherbatskoy, T. (1995). Wet deposition of mercury and ambient mercury concentrations at a site in the Lake Champlain Basin. Water Air Soil Poll. 80, 353-62.
Canadian Soil Information System [CANSIS] (2002). Canadian ecosdistrict climate normals 1961-1990. http://sis.agr.gc.ca/ cansis/nsdb/ecostrat/climate_normals_1961-90.html Agriculture and Agrifood Canada.

Clean Air Status and Trends Network (2004). Data compilations: http://www.epa.gov/castnet/data.html.

Cobbett, C.S. (2000). Phytochelatins and their roles in heavy metal detoxification. Plant Physiol. 123, 825-32.

Cohen, M., Artz, R., Draxler, R.P., Poissant, L., Niemi, D., Ratte', D., Deslauriers, M., Duval, R., Laurin, R., Slotnick, J., Nettesheim, F.T. and McDonald, J. (2004). Modeling the atmospheric transport and deposition of mercury to the Great Lakes. Environ. Res. 95, 247-65.

Dingman, S.L. (1981). Elevation: a major influence on the hydrology of New Hampshire and Vermont, USA. Hydrol. Sci. Bull. 26, 399-413.

Environment Canada - Energy, Mines and Resources Canada and Forestry Canada. (1993). Canada: Vegetation cover. National Atlas of Canada, 5th Edition. Map MCR 4182. National Atlas Information Service and Petawawa national Forestry Institute, Ottawa.

Environment Canada. (2004). Canadian National Atmospheric Chemistry (NAtChem) Database, http://www.msc.ec.gc.ca/ natchem/toxics/, Meteorological Service of Canada, 4905 Dufferin Street, Toronto, Ontario, Canada M3H 5T4.

Ericksen, J., Gustin, M.S., Schorran, D., Johnson, D., Lindberg, S. and Coleman, J. (2003). Accumulation of atmospheric mercury in forest foliage. Atmos. Environ. 37, 161322.

Gesch, D., Oimoen, M., Greenlee, S., Nelson, C., Steuck, M. and Tyler, D. (2002). The National Elevation Data Set. Photogramm. Eng. Rem. Sens. 68, 5.

Grigal, D.F. (2002). Inputs and outputs of mercury from terrestrial watersheds: a review. Environ. Rev. 10, 1-39.

Gustin, M.S., Johnson, D., Coleman, J. and Lindberg, S. (2003). Determining the role of plants and soils in the biogeochemical cycle of mercury on an ecosystem level. Final Report to EPA. Project\# R827622-02-0. 27 May 2003.

Hanson, P.J., Lindberg, S.E., Tabberer, T.A., Owens, J.G. and Kim, K.-H. (1995). Foliar exchange of mecury vapor: evidence for a compensation point. Water Air Soil Poll. 80, 373-82.

Johnson, D.W. and Lindberg, S.E. (1995). The biogeochemical cycling of $\mathrm{Hg}$ in forests: alternative methods for quantifying total deposition and soil emission. Water Air Soil Poll. 80, 1069-77.

Johnson, D.W., Benesch, J.A., Gustin, M.S., Schorran, D.S., Lindberg, S.E. and Coleman, J.S. (2003). Experimental evidence against diffusion control of $\mathrm{Hg}$ evasion from soils. Sci. Total Environ. 304, 175-84.

Kamman, N.C. and Engstrom, D.R. (2002). Historical and present fluxes of mercury to Vermont and New Hampshire lakes inferred from $210 \mathrm{~Pb}$ dated sediment cores. Atmos. Environ. 36, 1599-1609.

Kamman, N.C., Chalmers, A., Clair, Thomas A., Andrew, Major, Moore, Richard B., Norton, Stephen A. and Shanley, James B. (2005). Factors influencing mercury in freshwater surface sediments of northeastern North America. Ecotoxicology 14, 101-112. 
Kellerhals, M., Beauchamp, S., Belzer, W., Blanchard, P., Froude, F., Harvey, B., McDonald, K., Pilote, M., Poissant, L. and Puckett, K. (2003). Temporal and spatial variability of total gaseous mercury in Canada: results from the Canadian Atmospheric Mercury Measurement Network (CAMNet) Atmos. Environ, 1003-1011.

Landis, M.S., Stevens, R.K., Schaedlich, F. and Prestbo, E.M. (2002). Development and characterization of an annular denuder methodology for the measurement of divalent inorganic reactive gaseous mercury in ambient air. Environ. Sci. Tech. 36, 3000-3009.

Lawson, S.T. (1999). Cloud Water Chemistry and Mercury Deposition in a High Elevation Spruce-Fir Forest. M.S. Thesis. Univ. of Vermont School of Natural Resources, Burlington, VT 05405. $105 \mathrm{p}$.

Lee, X., Benoit, G. and Hu, X. (2000a). Total gaseous mercury concentration and flux over a coastal saltmarsh vegetation in Connecticut USA. Atmos. Environ. 34, 4205-13.

Lee, Y.H., Bishop, K.H. and Munthe, J. (2000b). Do concepts about catchment cycling of methylmercury and mercury in boreal catchments stand the test of time? Six years of atmospheric inputs and runoff export at Svartberget, northern Sweeden. Sci. Total Environ. 260, 11-20.

Lin, C.-J. and Pehkonen, S.O. (1999). The chemistry of atmospheric mercury: a review. Atmos. Environ. 33, 2067-79.

Lindberg, S.E., Dong, W. and Meyers, T. (2002). Transpiration of gaseous elemental mercury through vegetation in a subtropical wetland in Florida. Atmos. Environ. 36, 5207-19.

Lindberg, S.E., Hansen, P.J., Meyers, T.P. and Kim, K.-H. (1998). Air/Surface Exchange of Mercury over Forests - the need for a Reassessment of Continental Biogenic Emissions. Atmos. Environ. 32, 895-908.

Lindberg, S.E., Meyers, T.P., Taylor, G.E., Turner, R.R. and Schroeder, W.H. (1992). Atmosphere-surface exchange of mercury in a forest: results of modeling and gradient approaches. J. Geophys. Res. 97, 2519-28.

Lindberg, S.E. and Meyers, T.P. (2001). Development of an automated micrometeorological method for measuring the emission of mercury vapor from wetland vegetation. Wetlands Ecol. Manage. 9, 333-47.

Lindberg, S.E. and Stratton, W.J. (1998). Atmospheric mercury speciation: concentrations and behavior of gaseous mercury in ambient air. Environ. Sci. Tech. 32, 49-57.

Lindberg, S.E., Dong, W. and Meyers, T. (2002). Transpiration of gaseous mercury through vegetation in a subtropical wetland in Florida. Atmos. Environ. 36, 5200-19.

Lindberg, S.E., Brooks, S., Lin, C.-J., Scott, K.J., Landis, M.S., Stevens, R.K., Goodsite, M. and Richter, A. (2002). The dynamic oxidation of gaseous mercury in the Arctic atmosphere at polar sunrise. Environ. Sci. Tech. 36, 1245-56.

Malcolm, E.G. and Keeler, G.J. (2002). Measurements of mercury in dew: atmospheric removal of mercury species to a wetted surface. Environ. Sci. Tech. 36, 2815-21.

Malcolm, E.G., Keeler, G.J., Lawson, S.T. and Sherbatskoy, T.D. (2003). Mercury and trace elements in cloud water and precipitation collected on Mt. Mansfield Vermont. J. Environ. Mon. 4, 584-90.

Mason, R.P., Abbot, M.L., Bodaly, R.A., Bullock, O.R., Driscoll, C.T., Evers, D., Lindberg, S.E., Murray, M., and
Swain, E.B. (2005). Monitoring the Response to Changing Mercury Deposition. Environ. Sci Technol. 39, 14A-22A.

Miller, E.K., Panek, J.A., Friedland, A.J., Kadlecek, J. and Mohnen, V.A. (1993a). Atmospheric deposition to a highelevation forest at Whiteface Mountain, New York, USA. Tellus 45B, 209-27.

Miller, E.K., Friedland, A.J., Arons, E.A., Mohnen, V.A., Battles, J.J., Panek, J.A., Kadlecek, J. and Johnson, A.H. (1993b). Atmospheric deposition to forests along an elevational gradient at whiteface mountain, NY USA. Atmos. Environ. 27A, 2121-36.

Miller, E.K. and Friedland, A.J. (1999). Local climate influences on precipitation, cloud water, and dry deposition to an adirondack subalpine forest: insights from observations 1986-1996. J. Environ. Qual. 28, 270-77.

National Atmospheric Deposition Program (NRSP-3)/Mercury Deposition Network. (2004). NADP Program Office, Illinois State Water Survey, 2204 Griffith Drive, Champaign, IL 61820.

National Academy of Sciences (2000). Toxicological Profile for Methylmercury. National Academy Press, Washington, DC.

National Aeronautics and Space Administration [NASA] (2004). Shuttle Radar Topography Mission (SRTM) digital elevation data. http://seamless.usgs.gov U.S. Geological Survey Sioux Falls, SD.

Poissant, L. and Casimir, A. (1998). Water-air and soil-air exchange rate of total gaseous mercury measured at background sites. Atmos. Environ. 32, 883-93.

Poissant, L., Pilote, M., Xu, X. and Zhang, H. (2004). Atmospheric mercury speciation and deposition in the Bay St. Francois wetlands. J. Geophys. Res. 109, D11301-11302.

Poissant, L., Zhang, H., Gabrovska, D., Xu, X., Pilote, M. and Beauvais, C. (2004b). Air-Water- Soil- Vegetation Mercury gas exchanges in the Baie Saint-Franç cois. RMZ - Mater. Geoenviron. 51, 1719-21.

Poissant, L. (2000). Total gaseous mercury in Québec (Canada) in 1998. Sci. Total Environ. 259, 191-201.

Rasmussen, P.E. (1995). Temporal variation of mercury in vegetation. Water Air Soil Poll. 80, 1039-42.

Rea, A.W., Lindberg, S.E. and Keeler, G.J. (2001). Dry deposition and foliar leaching of mercury and selected trace elements in deciduous forest throughfall. Atmos. Environ. 35, 3453-62.

Rea, A.W., Lindberg, S.E., Scherbatskoy, T. and Keeler, G.J. (2002). Mercury accumulation in foliage over time in two northern mixed hardwood forests. Water Air Soil Poll. 133, 49-67.

Scherbatskoy, T., Shanley, J.B. and Keeler, G.J. (1998). Factors controlling mercury transport in an upland forested catchment. Water Air Soil Poll. 105, 427-38.

Schlesinger, W.H. (1977). Carbon balance in terrestrial detritus. Annu. Rev. Ecol. Syst. 8, 51-81.

Schwesig, D. and Matzner, E. (2000). Pools and fluxes of mercury and methylmercury in two forested catchments in Germany. Sci. Total Environ. 260, 213-23.

Shanley, J.B., Marvin-diPasquale, M., Schuster, P.F., Chalmers, A. and Reddy, M.M. (2004). Mercury methylation in forested uplands; how important is it? Eos Transactions $A G U$ 85(17), Joint Asembly Suppl., Abstract B24A-04. 
St. Louis, V.L., Rudd, J.W.M., Kelly, C.A., Hall, B.D., Rolfus, K.R., Scott, K.J., Lindberg, S.E. and Dong, W. (2001). Importance of the forest canopy to fluxes of methyl mercury and total mercury to boreal ecosystems. Environ. Sci. Tech. 35, 3089-98.

VanArsdale, A., Weiss, J., Keeler, G.J., Miller, E.K., Boulet, G., Brulotte, R., Poissant, L. and Puckett, K. (2005). Patterns of mercury deposition in northeastern North America (1996-2002). Ecotoxicology 14, 37-52.

VanHove, L.W., Heeres, P. and Bossen, M.E. (2002). The annual variation in stomatal ammonia compensation point of rye grass (Lolium perenne L.) leaves in an intensively managed grassland. Atmos. Environ. 36, 2965-77.
Vogelmann, J.E., Howard, S.M., Yang, L., Larson, C.R., Wylie, B.K. and Van Driel, N. (2001). Completion of the 1990s National Land Cover Data Set for the Conterminous United States from Landsat Thematic Mapper Data and Ancillary Data Sources. Photogramm. Eng. Rem. Sens. 67, $650-52$.

White, M.A., Running, S.W. and Thornton, P.E. (1999). The impact of growing-season length variability on carbon assimilation and evapotranspiration over 88 years in the eastern US deciduous forest. Int. J. Biometeorol. 42, 139-45.

Xu, X., Yang, X., Miller, D.R., Helble, J.J. and Carley, R.J. (1999). Formulation of bi-directional atmosphere-surface exchanges of elemental mercury. Atmos. Environ. 33, 4345-55. 